\title{
Assycuera, a new Neotropical genus of Ancylocerina (Coleoptera, Cerambycidae, Trachyderini) ${ }^{1}$
}

\author{
Dilma Solange Napp ${ }^{2}$ \\ Marcela Laura Monné ${ }^{2}$
}

\begin{abstract}
Assycuera gen. n. (type species: Anyclocera macrotela Bates, 1880) is proposed to accomodate four species formerly placed in Ancylocera Audinet-Serville, 1834: Assycuera waterhousei (White, 1855) comb. n., Assycuera macrotela (Bates, 1880) comb. n., Assycuera rubella (Bates, 1892), comb. n. and Assycuera scabricollis (Chemsak, 1963) comb. $\mathbf{n}$. The characters used to assemble these species into the new genus were mainly the gradually clavate femora and the antennae of the male with the $11^{\text {th }}$ segment elongate, filiform, the scape not enlarged at base and the pedicel not projected outerly. All the species are redescribed, illustrated and keyed. The males of Assycuera scabricollis and A. rubella are described for the first time. The key presented by Monné \& Napp (2000b) for the Neotropical genera of Ancylocerina is modified in order to include the new genus.

KEY WORDS. Ancylocerina, Cerambycinae, Assycuera, taxonomy, Trachyderini.
\end{abstract}

During the revisionary study of Ancylocera Audinet-Serville, 1834, it was found that A. macrotela Bates, $1880, A$. rubella Bates, 1892, A. scabricollis Chemsak, 1963 and $A$. waterhousei White, 1855, did not fit well in the genus, differing from $A$. cardinalis (Dalman, 1823), the type species, and other allied ones, in some important anatomical features. Therefore, a new genus is described herein to accomodate these species.

Ancylocerina Thomson, 1864 was recently treated by MONNÉ \& NAPP (2000b); they redescribed the subtribe, described Exallancyla Monné \& Napp, 2000 and Mimonneticus Monné \& Napp, 2000, and provided a key for the genera together with a brief taxonomical account on Ancylocerina. Six Neotropical genera were then known in the group, all of them described from South America. Otherwise, the species of Assycuera gen. n., are described from Mexico and Central America, except one, from northern Brazil.

Abbreviations cited in the text: (BMNH) The Natural History Museum, London; (CASC) California Academy of Sciences, California; (DZUP) Coleção de Entomologia Pe J.S. Moure, Departamento de Zoologia, Universidade Federal do Paraná, Curitiba; (MNHN) Muséum National d'Histoire Naturelle, Paris; (MNRJ) Museu Nacional, Universidade Federal do Rio de Janeiro, Rio de Janeiro; (MZSP) Museu de Zoologia, Universidade de São Paulo, São Paulo.

1) Contribuição número 1245 do Departamento de Zoologia, Universidade Federal do Paraná.

2) Departamento de Zoologia, Universidade Federal do Paraná. Caixa Postal 19020, 81531-990 Curitiba, Paraná, Brasil. Bolsista do CNPq e CAPES. 


\section{Assycuera gen. $\mathbf{n}$.}

Type species: Ancylocera macrotela Bates, 1880.

Form slender, elongate; body with sparse, erect, short, yellowish pubescence. Frons short, vertical, microcorrugate. Antennal tubercles strongly emarginate, moderately prominent, acuminate. Lower eye lobes moderately large, moderately prominent, the linkage with the upper lobes as wide or wider than one upper lobe; upper eye lobes well-separated on vertex, about half as wide as lower lobes. Genae short, acute. Mandibles rugosely punctate, somewhat enlarged, curved at apical third, acuminate at apex, fringed along inner border, lacking dorsobasal lobe in both sexes. Apical segment of palps, cylindrical, sligthtly attenuate at base and apex, as long as the preceding two combined.

Antennae 11-segmented, subserrate, longer than body in males, strongly serrate, reaching, at most, middle of elytra in females; segments 2-11 somewhat opaque, subglabrous and almost impunctate. Scape short, base as wide as apex, lacking laterobasal projections. Segment 2 without lateral outer projection. Segments 3-10 impressed and expanded apically. Segments 3-4 short, similar sized, as long as scape, shorter than 5, rounded at outer apex. Male with segments 5-9 subserrate, increasing in length, 7-8 about twice as long as 3; 11 elongate, filiform, little shorter than 10, appendiculate and curved at apex. Female with segments 5-10 short, strongly expanded, subequal in size, segment 5 little longer than all others; 11 as long or little longer than 10 , appendiculate, obliquely acuminate apically. Segments 3-4 with sensorial areas reduced, confined to ventral outer apex; 5-11 with a well developed sensorial system on dorsal and ventral surfaces, provided with a conspicuous, smooth, longitudinal carina; in male on apical third of segments 5-7, about half length of 7-9 and extending the entire length of 10-11; in female extending the entire length of segments from 6.

Prothorax elongate-cylindrical, subparallel at sides, basal margin somewhat produced at sides. Males with sexual punctation formed by minute, dense, shallow punctures, on apical and basal thirds of pronotum, sides of prothorax and prosternum, interspersed with coarser, deep punctures. Prosternum with intercoxal process narrow, subparallel between procoxae, feebly projected at apex, with small, lateral projections which fit into notches on coxae. Anterior coxal cavities small, rounded at sides, open behind. Mesosternum coarsely, irregularly punctate; intercoxal process subplane, as wide as mesocoxa, parallel-sided, with rounded, lateral projections which fit into notches on coxae, and medially notched at apex to fit metasternum. Intermediate coxal cavities closed to epimera. Metasternum subglabrous, with coarse, deep, irregularly sparse punctures. Scutellum small, subtriangular, impressed medially.

Elytra parallel-sided, about 2.5 times as long as the width across humeri; base slightly wider than prothorax, broadly semicircular, humeri somewhat projecting anteriorly; apices strongly declivous, truncate, shortly extended beyond abdominal apex, outer angle distinct, sutural angle somewhat produced. Surface shiny, very sparsely pubescent, coarsely, densely, subseriately punctate, the punctures becoming finer, denser, not seriate behind middle; at the sides of the suture with 2-3 irregular rows of moderately coarse punctures, becoming conspicuously finer, denser to subcontiguous, from basal third. Epipleura vertical, sinuous behind humeri. 
Legs moderately long, hind legs about 1.5-2 times as long as forelegs. Femora gradually clavate, smooth, subglabrous, almost impunctate. Metafemora spinose at inner apex, reaching elytral apex in male, shorter or slightly longer in female; dorsal surface with a moderately dense row of short, erect setae. Tibiae shorter than femora, somewhat impressed, not carinate, smooth, subglabrous; ventral surface with coarse, asperate punctures provided with moderately dense setae. Tibial spurs short. Tarsi short. First segment of metatarsi, at most, as long as the following two combined.

Urosternites strongly transverse, shiny, subglabrous; first urosternite with some coarse punctures on disk; second to fourth with fine, sparse punctures, denser at sides; fifth urosternite as wide as the preceding, finely, more densely punctate and pubescent. Female with the 8th urosternite provided with a brush of long setae arranged in several rows.

Remarks. The new genus differs from Ancylocera mainly by the shape of the femora and by the male antennae, features already pointed out by BATES (1880) when described Ancylocera macrotela. Since the females of both, Assycuera gen. n. and Ancylocera, have short, serrate antennae, they may be differenciated mainly by the gradually clavate or linear, compressed femora. Other differences are less conspicuous. In the females of Assycuera gen. n. the antennal scape is cylindrical, slightly curved, neither enlarged nor swollen at base, and the prosternum is densely punctate, leaving, as in male, only a narrow, almost smooth, median vitta. In the females of Ancylocera, on the other hand, the scape is curved and somewhat swollen at base, showing wider than the apex, and the prosternum is sparsely punctate.

Of the four species here included in Assycuera gen. n., two were described from Neotropical Mexico, and one from Nicaragua. The only South American representative, $A$. waterhousei, is a very distinctive species and it is tentatively included in the new genus (see Remarks under $A$. waterhousei). Judging by the literature, all the species are poorly known. Except for E. macrotela, the original descriptions of the species were based each on a single female, and subsequent papers are catalogues or simply with distributional data. Hosts and immatures are not known.

Etymology. Assycuera is an indigenous word, from Tupi, meaning brother or sister.

The key for the Neotropical genera of Ancylocerina presented by MONNÉ \& NAPP (2000b) is here adapted in order to include Assycuera gen. n., as follows:

4 (3). Antennae of male with segments 3-4 short, impressed and strongly expanded; segments 5-8 successively elongate, 7-8 almost twice as long as $3 ; 11$ strongly reduced or, at least, shorter than 10 . Antennae of female with segments 3-10 short and strongly expanded, with the apical width subequal to length; segment 5 as long or longer than 3; segments 10-11 similar sized. Sensorial system of segments $3-4$, in both sexes, reduced and usually confined to the ventral apex. Femora abruptly or gradually clavate (except A. waterhousei, linear, compressed) ................. 4a 
- Antennae, in both sexes, subserrate, with segment 3 as long or longer than the following, 11 longer than 10. Antennae of female with segments 3-8 about 1.5-2 times as long as the width at apex; segment 11 (or 10) conspicuously longer than the preceding. Sensorial system well developed on dorsal and ventral surfaces of all antennal segments. Femora cylindrical . . . . . . . 5

$4 \mathrm{a}(4)$. Femora pedunculate, abruptly clavate. Antennae of male with segment 11 strongly reduced, hook-like; scape broader at base, with lateral outer and/or inner projections; segment 2 conspicuously projected at outer apex; segments $6-10$ almost cylindrical, enlarged only at apex .............. ......................... Ancylocera Audinet-Serville, 1834

- Femora gradually clavate or linear, compressed. Antennae of male with segment 11 elongate, slightly shorter than 10; scape lacking laterobasal projections, base as broad as apex; segment 2 not projected at outer apex; segments 6-10 subserrate, slightly expanded from base to apex ........ Assycuera gen. $\mathbf{n}$.

\section{Key to the species of Assycuera gen. $\mathbf{n}$.}

1. Elytra bicolor, orangish with the apical third black to brownish. Female: metafemora linear, compressed, exceeding elytral apices; antennae barely reaching humeri; prothorax longer than half length of elytra. (Fig. 1). BRAZIL (Amapá, Amazonas, Pará) ............. A. waterhousei (White, 1855) comb. n.

- Elytra entirely orangish. Female: metafemora gradually clavate, shorter than elytra; antennae reaching middle of elytra; prothorax shorter than half length

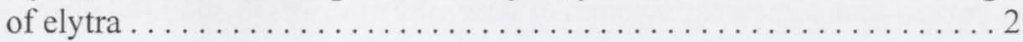

2(1). Head, prothorax, elytra and undersurface, orangish-red. Male: mesofemora with a short spine at inner apex. (Antennae of male exceeding elytral apices by one segment). (Figs 2, 5). MEXICO (Guerrero, Jalisco, Nayarit) . . .

A. rubella (Bates, 1892) comb. n.

- Head, prothorax, meso- and metasternum black, elytra orangish-red. Male: mesofemora dentate at inner apex . . . . . . . . . . . . . . . . 3

3(2). Male: middle of pronotum transversely rugose punctate; apical and basal thirds of pronotum, sides of prothorax and prosternum subopaque, with very dense, minute sexual punctation, interspersed with shallow, moderately dense punctures. Female: pronotum transversely rugose punctate throughout; sides of prothorax and prosternum with smaller, shallow, dense punctures, not corrugate; mesofemora with a short spine at inner apex. (Figs 3, 6). MEXICO, GuATEMALA, HONDURAS, NicARAGUA

A. macrotela (Bates, 1880) comb. $\mathbf{n}$.

- Male: middle of pronotum coarsely, densely puncate, not transversely rugose; apical and basal thirds of pronotum, sides of prothorax and prosternum shiny, the sexual punctation weakly conspicuous, interspersed with moderately coarse, deep, subcontiguous punctures. Female: pronotum and sides of prothorax coarsely, confluently punctate, punctation of prosternum sparser; mesofemora rounded at apex. (Figs 4, 7). Mexico (Mexico, Guerrero) .... A. scabricollis (Chemsak, 1963) comb. $\mathbf{n}$. 


\section{Assycuera waterhousei (White, 1855) comb. $\mathbf{n}$.}

Fig. 1

Ancylocera waterhousei White, 1855: 211; Buquet, 1857: 138; Lacordaire, 1869: 137; Bates, 1870: 418; Aurivillius, 1912: 446; Blackwelder, 1946: 587; Zajciw, 1961: 530; Viana, 1971: 199; Monné, 1994: 19; Monné \& Giesbert, 1995: 140.

Female. Head, antennae and prothorax black, basal half of the sides of prothorax and middle of prosternum reddish-black; legs black to brownish, femora paler at base; elytra orangish with the apical third black to brownish; mesosternum, metasternum and urosternites orangish. Frons subangulate between antennal tubercles, which are prominent, acute, obliquely directed upwards. Mandibles opaque. Genae densely punctate, about $1 / 3$ as long as lower eye lobes. Vertex scabrous, with very deep, contiguous punctures. Antennae barely surpassing humeri. Scape irregularly rugose punctate throughout. Segments 3-7 conspicuously, broadly impressed at base; segments 6-10 somewhat quadrangular, strongly expanded from base, which is as wide as the apex; 11 longer than 10. Prothorax almost twice as long as broad, longer than half length of elytra; parallel at sides, attenuate at apex, broader at base. Pronotum very densely, deeply punctate throughout, the punctures opaque, contiguous. Sides of prothorax similary punctated, the punctures coarser and shallower. Prosternum with coarse, deep punctures, sparser at middle. Scutellum strongly reduced, weakly conspicuous. Elytra with two rows of dorsal, coarse punctures extending from base to behind middle, and two rows of finer punctures along the suture at basal half, the punctation becoming finer and denser apically. Femora slender, compressed. Mesofemora dentate at inner apex. Metafemora shortly exceeding elytral apices, the inner apical spine about half as long the femoral apical width. First segment of metatarsi slightly longer than the following two combined. Fifth urosternite broadly rounded truncate at apex.

Measurements, in milimeters, female. Total length, 9.5-10.7; prothorax length, 3.3-3.7; prothorax width, 1.8-2.2; elytral length, 5.3-6.2; humeral width, 2.0-2.3.

Types. A female sintype (Fig. 1) (BMNH), from Tapajós, Pará, Brazil, was examined by means of color photographs.

Remarks. Assycuera waterhousei is unique in having a very elongate prothorax; short antennae barely surpassing the humeri; linear, compressed femora, the hind pair exceeding the elytral apices; strongly reduced scutellum; and bicolored elytra. In addition, it is the only species hitherto known from South America.

WHITE (1855), in describing Ancylocera waterhousei, did not mention the sex, either the length of the antennae of the specimen. Apparently, he based on more than one example since two measurements were given. The example labelled as type is a female (Fig. 1) which belonged to Bate's Collection and was recorded from "Amazon (Tapayos)" (WHITE 1855). BATES (1870) redescribed the species based on a single example, also recorded from Tapajós and with the same length of one of White's examples. Despite the indication of " $\mathrm{o}$ " given by Bates, the antennae were described as not reaching the middle of the elytra, having short, impressed, serrate segments. Therefore, it is not certain weather Bate's example was a male. 

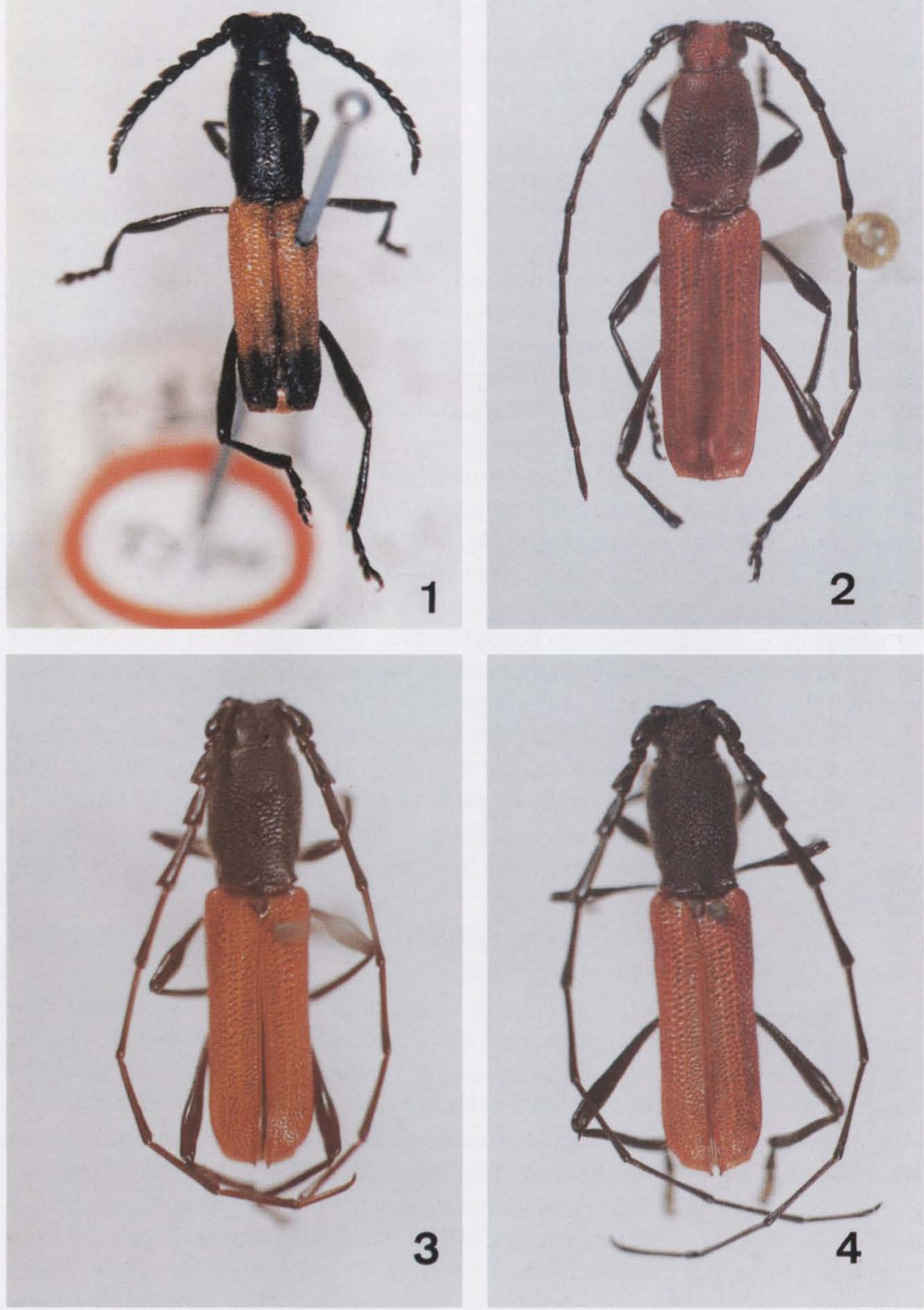

Figs 1-4. (1) Assycuera waterhousei, female sintype; (2) A. rubella (Bates), male; (3) A. macrotela, male; (4) A. scabricollis, male. 
Subsequently, this species has been referred only in catalogues. So, it may be possible that the male of $A$. waterhousei is not yet known.

Considering the unique features of $A$. waterhousei mentioned above together with its distributional range, and because male examples were not available to the present study, this species is provisionally included in the new genus. An examination of male examples is required in order to corroborate the present assignment.

Specimens examined. BRAZIL, Amapá: Serra do Navio, 1 female, IX.1957, K. Lenko leg. (MNRJ). Pará: Óbidos, 1 female, 1940 (MNRJ).

\section{Assycuera rubella (Bates, 1892) comb. $\mathbf{n}$.}

Figs 2, 5

Ancylocera rubella Bates, 1892: 170, pl. 7, fig. 8; Aurivillius, 1912: 446; Blackwelder, 1946: 587; Chemsak, 1963: 105; Viana, 1971: 198; Chemsak et al., 1992: 78; Monné, 1994: 18; Monné \& Giesbert, 1995: 140; Chemsak \& Noguera, 1995: 63; Noguera \& Chemsak, 1996: 402.

Male. Integument orangish-red, the elytra paler, antennae and legs black to brownish, base of femora and antennal scape feebly reddish. Frons subplane between antennal tubercles. Genae punctocorrugate, shorter than half lower eye lobes. Vertex, coarsely, densely, punctorugose. Antennae exceeding elytral apices by one segment. Scape with coarse punctures, longitudinally rugose punctate at base. Prothorax 1/3 longer than broad, feebly attenuate to apex and base, slightly wider at base. Center of pronotum with coarse, deep, subcontiguous punctures, in one example transversely rugose punctate. Apical and basal $1 / 4$ of pronotum, sides of prothorax and prosternum with smaller, shallower, dense to contiguous punctures, the sexual punctation weakly conspicuous. Prosternum with a median, narrow vitta, sparsely, coarsely punctate. Elytra with coarse, subcontiguous punctures, subseriate at basal half, becoming finer, denser, not seriate apically, more conspicuously so at the sides of the suture. Mesofemora with a short spine at inner apex. Metafemora reaching elytral apex, the inner apical spine half as long as the femoral apical width. First segment of metatarsi little shorter than the following two combined. Fifth urosternite broadly rounded truncate at apex.

Female. Antennae reaching midlle of elytra; scape slender than in male; segment 11 slightly longer than 10. Prothorax lacking sexual punctation, somewhat rounded at sides. Pronotum coarsely, contiguously punctate throughout; sides of prothorax and prosternum densely punctate, the punctures coarser and shallower than in male. Metafemora shorter than elytra, the inner apical spine longer than in male. Fifth urosternite truncate at apex.

Measurements, in mm, male/female. Total length, 9.5-10.7/8.2; prothorax length, 3.0-3.5/2.6; prothorax width, 2.0-2.3/1.7; elytral length, 5.5-6.4/5.0; humeral width, 2.2- 2.5/1.8.

Types. BATES (1892) based on a single female from Acapulco, Mexico. The holotype (BMNH) was studied by means of color photographs. According to the original description, the middle of the prosternum, the mesosternum and the sides of the metasternum are black. 
Remarks. The concolor reddish head, prothorax and elytra differenciates $A$. rubella from the others. In addition, the male antennae, at least in the three examples studied, exceed the elytral apices by only one segment, though the male antennae may be quite variable in length within the Ancylocerina (VIANA 1971; MONNÉ \& NAPP 2000a,b). This species was hitherto known only from the female holotype and records from Mexico only (Guerrero, Jalisco); a new record from Nayarit is added. CHEMSAK \& NOGUERA (1995) noticed examples collected on flowers of Caesaria, Croton and Serjania.

Specimens examined. Mexico, Nayarit: San Blas, 1 male, 1 female, VIII. 1972 (MZSP), 1 male, VII.1972, 1 male (200m), VI.1968, A. Martinezleg. (MNRJ).

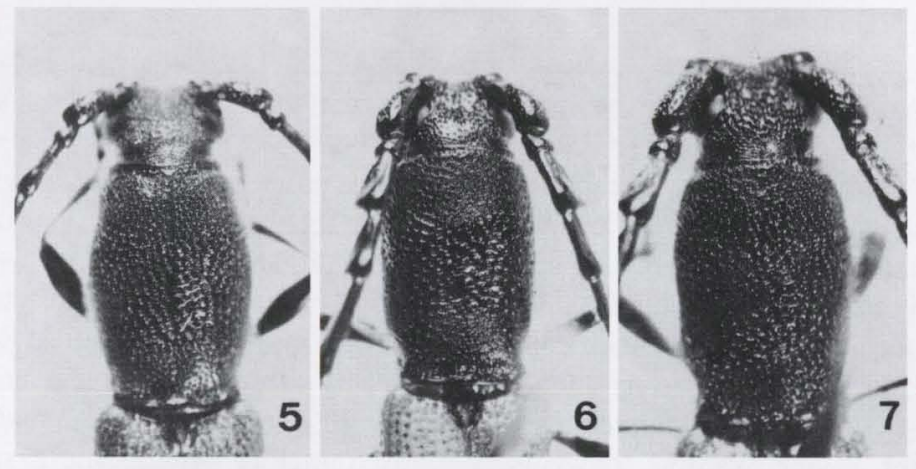

Figs 5-7. Prothorax, male. (5) Assycuera rubella; (6) A. macrotela; (7) A. scabricollis.

\section{Assycuera macrotela (Bates, 1880) comb. $\mathbf{n}$.}

Figs 3,6

Ancylocera macrotela Bates, 1880: 68; 1885: 314; Lameere, 1883: 43; Aurivillius, 1912: 446; Blackwelder, 1946: 587; Chemsak, 1963: 106; 1964: 110; Chemsak \& Linsley, 1970: 406; Viana, 1971: 198; Chemsak et al. 1980: 32; Chemsak et al. 1992: 78; Monné, 1994: 18; Maes et al., 1994: 8; Monné \& Giesbert, 1995: 140; Noguera \& Chemsak, 1996: 402.

Ancylocera rugicollis; Bates, 1872: 191 (non Fabricius, 1801).

Male. Head, prothorax, meso- and metasternum black; antennae and legs black to brownish, base of femora paler; scutellum, elytra and urosternites orangish. Frons angulate between antennal tubercles. Genae almost half as long as lower eye lobes, finely, sparsely punctate. Vertex with coarse punctures, irregularly dense to corrugate between antennal tubercles. Antennae exceeding elytral apices by almost three segments. Scape sparsely punctate, the punctures denser at base and outer surface; segment 11 about $1 / 4$ shorter than 10 . Prothorax about $1 / 3$ longer than broad, subparallel at sides, more attenuate at base. Center of pronotum shiny, coarsely, densely, transversely rugose punctate; apical and basal thirds opaque, with very dense sexual punctation, interspersed with moderately dense punctures, which are smaller, shallower and sparser than those of the center of pronotum. Sides of prothorax and prosternum subopaque, the punctation similar to that of the apical 
and basal thirds of pronotum. Prosternum with a median, narrow, shiny vitta, with scattered coarse punctures. Metasternum with very coarse, deep punctures, irregularly sparse. Elytra, at base, with smaller, not seriate puntures; dorsum with three dorsal rows of coarse punctures extending from basal to apical third; on each side of the suture with fine, dense, not seriate punctures from basal third to apex. Mesofemora slightly dentate at inner apex. Metafemora reaching or exceeding elytral apices, the inner apical spine $2 / 3$ as long as the femoral apical width. First segment of metatarsi little shorter than the following two combined. Fifth urosternite broadly rounded truncate at apex, barely sinuate at middle.

Female. Antennae reaching or slightly exceeding the middle of elytra; scape slender, denser punctate; segment 11 little longer than 10. Sides of prothorax somewhat rounded. Pronotum and sides of prothorax shiny, coarsely, densely, rugosely punctate, the punctures smaller on apical and basal thirds of pronotum; sexual punctation lacking. Prosternum coarsely, deeply, densely punctate to corrugate, with a broad, median vitta with coarse, sparse punctures. Mesofemora with a moderately long spine at inner apex. Inner apical spine of metafemora almost as long as the femoral apical width. Fifth urosternite slightly sinuate at apex.

Measurements, in mm, male/female. Total length, 11.8/12.0; prothorax length, 3.7/3.5; prothorax width, 2.5/2.7; elytral length, 7.0/7.2; humeral width, 2.7/2.8.

Types. BATES (1880) based on examples of both sexes recorded from Guatemala (San Gerônimo) and Nicaragua (Chontales). CHEMSAK \& LinSLEY (1970) designated the male from Chontales, Nicaragua, as Lectotype (BMNH).

Remarks. Assycuera macrotela is similar to A. scabricollis, differing mainly by the characters that were given in the key. CHEMSAK (1963) in redescribing Ancylocera macrotela, mentioned that the male antennae exceed the elytral apices by only one segment, corroborating with the length variation of the male antennae. This species has been recorded from the Neotropical part of Mexico (Chiapas, Morelos, Puebla) and distributes southwards through Guatemala (San Gerônimo, Sacapulas), Honduras (Comayagua, La Paz, Santa Barbara, Lempira, F. Morazan) and Nicaragua (Chontales).

Specimens examined. Guatemala: 1 male, Ex. Musaeo Mniszech, Museum Paris, ex. Coll. R. Oberthur (MNHN). Sacapulas (4500 ft), 1 female, 12.VIII.1947, F. Johnson, C. \& P. Vaurie leg. (MZSP).

\section{Assycuera scabricollis (Chemsak, 1963) comb. n.} Figs 4,7

Ancylocera scabricollis Chemsak, 1963: 106; Viana, 1971: 199; Chemsak et al. 1992: 78; Monné, 1994: 19; Monné \& Giesbert, 1995: 140; Noguera \& Chemsak, 1996: 402.

Male. Head, prothorax, meso- and metasternum, scutellum, antennae and legs black to brownish; elytra and urosternites orangish. Frons angulate between antennal tubercles, which are prominent, obliquely pointing upwards. Genae almost half as long as lower eye lobes, with fine and coarse punctures intermingled. Vertex scabrous, with deep, contiguous punctures, the punctation finer between antenal tubercles. Antennae exceeding elytral apices by 2.5-3 segments. Scape with coarse 
punctures, longitudinally rugose punctate at base. Segment 11 about $1 / 4$ shorter than 10. Prothorax cylindrical, subparallel at sides, more attenuate at base. Middle of pronotum with coarse, deep, dense to subcontiguous punctures, not transversely rugose; apical and basal thirds shiny, with smaller, very dense punctures, the sexual punctation weakly conspicuous. Sides of prothorax and prosternum shiny, with moderately fine, deep, contiguous punctures, the sexual punctation weakly conspicuous. Median vitta of prosternum indistinct, coarsely, densely punctate. Metasternum with very coarse, deep punctures, which are moderately, irregularly dense. Elytra with subseriate punctures from base to beyond middle; with two rows of fine punctures at the sides of the suture and two rows of coarser, dorsal punctures, the punctation gradually finer and denser behind middle, more conspicuously so near suture. Mesofemora dentate at inner apex. Metafemora almost reaching elytral apices, the inner apical spine shorter than half the femoral apical width. First segment of metatarsi almost as long as the following two combined. Fifth urosternite slightly sinuous at apex.

Female holotype. Genae opaque, impunctate. Antennae reaching middle of elytra; scape slender, with coarse punctures, which are dense to corrugate at base and outer surface; segment 11 little longer than 10. Prothorax attenuate at base and apex, slightly broader at base, lacking sexual punctation, with coarse, deep, confluent punctures throughout, sparser on prosternum. Scutellum reddish. Mesofemora rounded at apex. Metafemora shorter than elytra, the inner apical spine about half as long as the apical width of femora. Fifth urosternite broadly rounded at apex.

Measurements, in mm, male/female. Total length, 9.8-11.4/10.8; prothorax length, 2.8-3.3/3.0; prothorax width, 2.0-2.2/2.2; elytral length, 5.8-6.8/6.7; humeral width, 2.2-2.5/2.3.

Types. CHEMSAK (1963) based on a single female, recorded from the State of Mexico (CASC). The holotype was examined.

Remarks. Assycuera scabricollis was known only by the female holotype recorded from Mexico. A new record from Guerrero (Mexico) is given.

Specimens examined. Mexico: Mexico, 1 male, 1950, M. Zantino leg. (MZSP); 1 female (holotype), 1950, F.D. Parker leg. (CASC). Guerrero: Buenavista de Cuellar, 1 male, VII.1968, A. Martinez leg. (MNRJ).

ACKNOWLEDGMENTS. We are grateful to David H. Kavanaugh (CASC) for the loan of the holotype of Ancylocera scabricollis. A special thanks also to Albino M. Sakakibara (DZUP) for the revision of the english manuscript and for taking the photographs.

\section{REFERENCES}

AURIVII.LIUS, C. 1912. Coleopterorum Catalogus, pars 39, Cerambycidae: Cerambycinae. Berlin, W. Junk, 574p.

BAtes, H.W. 1870. Contributions to an insect fauna of the Amazon Valley (Coleoptera). Trans. Ent. Soc. London 1870: 391-344.

-1872. On the longicorn Coleoptera of Chontales, Nicaragua. Trans. Ent. Soc. London 1872: $163-238$.

1880. In: F.D. Godman \& O. SALvin. Biologia Centrali Americana. Insecta. Coleoptera. London, Vol. 5, p. 17-152. 
1885. In: F.D. Godman \& O. Salvin. Biologia Centrali Americana. Supplement to Longicornia. Vol. 5, p. 249-436.

- 1892. Additions to the Longicornia of Mexico and Central America, with remarks on some previously recorded species. Trans. Ent. Soc. London 1892: 143-183.

BLACKWELDER, R.E. 1946. Checklist of the coleopterous insects of Mexico, Central America, the West Indies and South America. Part 4. Bull. U.S. Nat. Mus. 185: 551-763.

BUQUet, J.B. 1857. Lettre sur le genre Ancylocera de la famille des cérambycides. Archiv. Ent., Paris, 1: $137-138$.

Chemsak, J.A. 1963. Synopsis of the genus Ancylocera in Mexico (Coleoptera, Cerambycidae). Jour. Kansas Ent. Soc. 36 (2): 104-109.

- 1964. A new species of Mexican Ancylocera with records of others. (Col., Cerambycidae). Ent. News 75 (4): 108-110.

Chemsak, J.A. \& E.G. Linsley. 1970. Additional designations of lectotypes of neotropical Cerambycidae in the collections of the British Museum (Natural History) (Coleoptera). Jour. Kansas Ent. Soc. 43 (4): 404-417.

Chemsak, J.A.; E.G. Linslliy \& F.A. Noguera. 1992. Listados faunísticos de México. II. Los Cerambycidae y Disteniidae de Norteamérica, Centroamérica y las Indias Occidentales (Coleoptera). México, Univ. Nacional Autónoma México, 204p.

ChEmSAK, J.A.; E.G. Linsley \& J.V. MAnkins. 1980. Records of some Cerambycidae from Honduras (Coleoptera). Pan-Pacif. Ent. 56 (1): 26-37.

Chemsak, J.A. \& F.A. Noguera. 1995. Annotated checklist of the Cerambycidae of the Estacion de Biologia Chamela, Jalisco, Mexico (Coleoptera), with descriptions of a new genera and species. Folia Ent. Mex. 89: 55-102.

Lacordaire, J.T. 1869. Histoire Naturelle des Insectes. Genera des Coléoptères. Paris, Librerie Encyclopedique de Roret, 9 (1): 1-409.

LAmeERE, A.A. 1883. Liste des cérambycides, décrits postérieurement au catalogue de Munich. Ann. Soc. Ent. Belg. 26: 1-78.

MAEs, J.M.; A. Allen; M.A. MonNÉ \& F.T. Hovore. 1994.Catalogo de los Cerambycidae (Coleoptera) de Nicaragua. Revta Nicar. Ent. 27: 1-58.

MonNÉ, M.A. 1994. Catalogue of the Cerambycidae (Coleoptera) of the Western Hemisphere. XI. São Paulo, Soc. Bras. Ent., 157p.

MonnÉ, M.A. \& E.F. GiesberT. 1995. Checklist of the Cerambycidae and Disteniidae (Coleoptera) of the Western Hemisphere. Burbank, Wolfsgarden Books, XIII+419p.

Monné, M.L. \& D.S. Napp. 2000a. Revisão do gênero Ceralocyna (Coleoptera, Cerambycidae, Cerambycinae, Trachyderini, Ancylocerina). Iheringia, Sér. Zool., Porto Alegre, (88): 103-137. 2000b. Two new South American genera of Ancylocernina (Cerambycidae, Cerambycinae, Trachyderini). Coleopts Bull. 54 (3): 351-358.

Noguera, F.A. \& J.A. Chemsak. 1996. Cerambycidae (Coleoptera), p. 381-409. In: J.L. Bousquets; A.N.G. Aldrete \& E.G. Soriano (Eds). Biodiversidad, Taxonomia y Biogeografia de Artrópodos de México: Hacia una síntesis de su conocimiento. México, Univ. Nacional Autónoma México, 660p.

VIANA, M.J. 1971. Las espécies argentinas de Ancylocerini Thomson y catálogo bibliográfico de la tribu (Coleopt., Cerambycidae, Cerambycinae). Revta Mus. arg. Cienc. nat. Bernardino Rivadavia, Entom., 3 (3): 149-205.

WhiTE, A. 1855. Catalogue of the coleopterous insects in the collection of the British Museum. 8. Longicornia 2, London, p. 175-412.

Zascrw, D.1961. Insecta Amapaensia (Coleoptera, Cerambycidae). Studia Ent. 4 (1-4): 525-536.

Recebido em 15.XII.2000; aceito em 28.VIII.2001. 